\title{
TTR
}

Traduction, terminologie, re?daction

\section{Fernando Poyatos ed. Nonverbal Communication and Translation. Amsterdam/Philadelphia, John Benjamins, 1997.}

\section{Louise von Flotow}

Volume 10, numéro 1, 1er semestre 1997

Langues, traduction et post-colonialisme

Languages, Translation and Post-Colonialism

URI : https://id.erudit.org/iderudit/037289ar

DOI : https://doi.org/10.7202/037289ar

Aller au sommaire du numéro

\section{Éditeur(s)}

Association canadienne de traductologie

ISSN

0835-8443 (imprimé)

1708-2188 (numérique)

Découvrir la revue

Citer ce compte rendu

von Flotow, L. (1997). Compte rendu de [Fernando Poyatos ed. Nonverbal Communication and Translation. Amsterdam/Philadelphia, John Benjamins, 1997.] TTR, 10(1), 301-303. https://doi.org/10.7202/037289ar d'utilisation que vous pouvez consulter en ligne.

https://apropos.erudit.org/fr/usagers/politique-dutilisation/ 


\section{COMPTES RENDUS}

\section{Fernando Poyatos ed. Nonverbal Communication and Translation. Amsterdam/Philadelphia, John Benjamins, 1997.}

The fact that non-verbal communication may be problematic to translate may seem evident. The complexity of "paralinguistic and kinesic" representation is, however, made very clear in this collection of essays, a collection that will encourage translators and theorists to reconsider the important issues in their work.

The collection opens with two essays that present theoretical terminology and discuss some of the basic issues in the field of nonverbal communication. Fernando Poyatos' text draws on his many earlier publications and gives a detailed discussion, rich in examples, of the many types of non-verbal communication. Basil Hatim applies text linguistics and discursive theory to analyze "graphically representational" language and language with a political spin. Differentiating this language from what he calls an unmarked "core" lexis, he concludes that marked or motivated language is always also a feature of 'genre' and 'text' types to which attention must be paid in text transfer activities.

The next section - "Cultures in Translation" - consists of two essays on gestures in Chinese and Japanese cultures. Here the issue is less one of translation than of helping Western cultures (and presumably translators) understand gestural differences. Yau Shun-chiu discusses Chinese gestures and differentiates their usage in a number of areas of Chinese culture, while Rie Hasada focuses on "Japanese cultural ethos" as it becomes evident in eye movement and eye contact as well as the non-verbal activities of smiling and crying.

In section three - "Narrative Literature" - four essays deal with aspects of non-verbal communication in narrative texts from different cultures. In an article on the translations of Alice in Wonderland, Christiane Nord argues for the "functional" approach in transferring "paralinguistic behaviouremes". Every language (and every one of its 'genre' and 'text' types), she says, will use non-verbal communication 
differently, and every translation needs to adapt this communication differently. Translations that stick too closely to Lewis Carroll's "British understatement" end up reading like a Spanish or French text "with a strong British accent". Kirsten Malmkjaer's text on the idiosyncracies of Andersen's punctuation and its translations makes a case for translators observing punctuation, and argues against Nord, asserting that target language normalization of punctuation "disregards a writer's manner of telling". The other two essays, Pierangela Diadori's text on translating gesture in I Promessi Sposi and Y ishai Tobin's work on an oral Holocaust memoir and its translation into written form, are largely descriptive. Diadori demonstrates the importance of gestural language in a $19^{\text {th }}$ century work and the problems involved in translating obsolete gestures, while Tobin shows how verb choices in the written (translated) version of a Holocaust memoir function on a paralinguistic level.

Two essays on translation of theatre texts develop the problem of gestures that are implied in the written text. Drawing on examples from Tom Stoppard and Thomas Bernhard, Mary Snell-Hornby examines the interplay between visual and acoustic signs, which are the basis of work for the theatre, and the verbal element which is all the translator can work with. Said-El Shizab discusses the Arabic translations of two Shakespeare plays.

Sean Golden's work on non-verbal elements in the translation of poetry focuses on the physical, aural, visual and social aspects of prosody and genre. Taking examples from Chinese, Welsh, Latin and Spanish, he presents a fascinating study of how the breath/breathing of poetry, its aspect on the page, and its sound are formal properties which, though non-verbal, are intrinsic features of the writing, and its translation.

Three articles on non-verbal aspects of interpreting follow; Poyatos' introductory piece presents and explains concepts and categories in considerable detail; Sergio Viaggio and Edna Weale, both working interpreters, move from the theoretical to the practical approach to show exactly how vital kinesics (here, the speakers' and interpreters' body language) and other non-verbal aspects of speech are to the message that is being conveyed, and interpreted. Viaggio focuses on the 'visual channel' as an integral support for the comprehension and transfer of the acoustic input, while Weale deals with the processes used to 'unscramble' 
conference texts that have been scrambled by non-verbal and culturally distinct communication.

Two texts on audio-visual translation, here, film and TV dubbing, complete the collection. Frederic Chaume Varela bases his work on the assertion that audio-visual texts are a separate genre, clearly marked by the interaction between verbal and non-verbal (visual) information. They require culturally sensitive and appropriate handling of the paralanguage, kinesics and proxemics. Lack of attention to these important non-verbal features leads to "the steady invasion of target cultures that are unable to export their own products yet consume large numbers of imported film". Patrick Zabalbeascoa studies audio-visual translation as a genre that stretches the conventional definitions and categorizations of translation, since it clearly demonstrates the importance of non-verbal elements in communication. While dubbing may be an extreme case, ad copy, comics and other text types are all marked by nonverbal elements, as the collection of essays has shown. Theoretical approaches to translation need to be rethought to incorporate this nonverbal aspect of all texts.

This collection of essays presents diverse issues in the field of non-verbal communication and the challenges it poses to translation. It is a useful introduction for those, like myself, who have never thought about the problem, and will doubtless be of interest to those more advanced in the field. And although a number of the articles read "like English with a heavy foreign accent", most of the material is accessible and interesting.

Louise von Flotow
University of Ottawa 